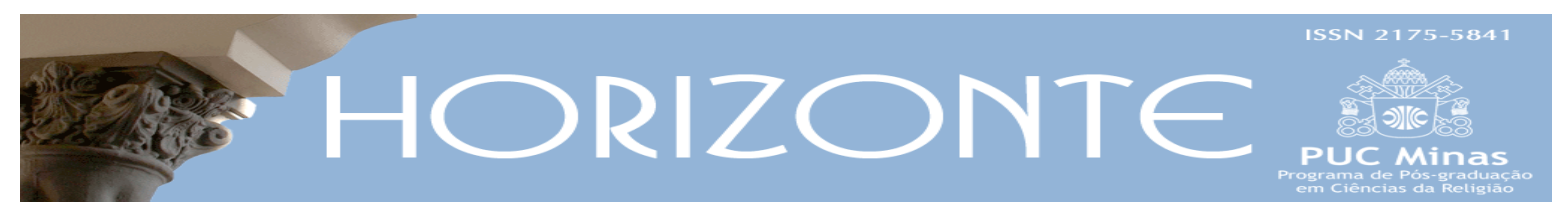

Dossiê: Teorias de linguagem e Estudos de Religião - Artigo Original ๑용

DOI - 10.5752/P.2175-5841.2018v16n51p1197

\title{
A poética e a linguagem religiosa em Paul Ricoeur
}

\author{
Poetics and religious language in Paul Ricoeur
}

\author{
Ivanaldo Oliveira Santos* \\ Marcio Lima Pacheco**
}

\begin{abstract}
Resumo
O objetivo deste artigo é traçar como, no pensamento de Paul Ricœur, a narração e a sua especificidade da linguagem religiosa permeiam um acontecimento in illo tempore que dá ao ser humano uma orientação temporal que carrega um acontecimento passado para um futuro que, em certo sentido, é preenchido pela esperança e, com isto, coroando o esforço do existir do ser humano. $\mathrm{O}$ artigo fundamenta-se principalmente nas obras de Ricœur, tais como: $O$ conflito das interpretações, $A$ hermenêutica bíblica, Manifestation et Proclamation e Do texto à ação. Discute-se a questão de, em Ricœur, a linguagem religiosa oferecer a garantia do acolhimento da revelação como palavra inacessível e, com isso, faz com que o ser humano decida por essa como um dom gratuito. Ela redescreve a realidade. Um processo realizado por meio da linguagem metafórica e simbólica. Neste sentido, o símbolo tem um sentido que pode ser reapropriado por quem o interpreta. Por fim, afirma-se que, em Ricœur, o texto sagrado, especificamente o texto bíblico, é uma janela aberta, uma possibilidade tanto do processo ético de nomeação de Deus como também da abertura e da complexidade poética da construção do texto.
\end{abstract}

Palavras-chaves: Ricœur; linguagem religiosa; poética; texto.

\begin{abstract}
The purpose of this article is to outline how, in Paul Ricœur's thought, narration and its specificity of religious language permeates an event in illo tempore that gives the human being a temporal orientation that carries a past event to a future that, in a sense, is filled by hope and, with it, crowning the effort of the human being's existence. The article is mainly based on the works of Ricœur, like for: The conflict of the interpretations, The biblical hermeneutics, Manifestation et Proclamation and Du texte à I'action. Essais d'herméneutique II. The issue is discussed, in Ricœur, that religious language offers the guarantee of receiving revelation as an inaccessible word and, therefore, makes the human being decide for it as a gratuitous gift. It redefines reality. A process performed through metaphoric and symbolic language. In this sense, the symbol has a meaning that can be reappropriated by those who interpret it. Finally, it is stated that in Ricœur the sacred text, specifically the biblical text, is an open window, a possibility both of the ethical process of naming God and of the openness and poetic complexity of the construction of the text.
\end{abstract}

Keywords: Ricœur; religious; poetic language; text.

Artigo recebido em 16 de junho de 2017 e aprovado em 24 de agosto de 2018.

*Doutor em estudos da linguagem pela UFRN. Professor do Departamento de Filosofia e do Programa de Pós-Graduação em Letras da Universidade do Estado do Rio Grande do Norte (UERN). País de origem: Brasil. E-mail: ivanaldosantos@yahoo.com.br

** Doutor em Filosofia pela Pontifícia Universidade Católica de São Paulo (PUC-SP). Professor do Departamento de Filosofia na Universidade Federal de Rondônia (UNIR). País de origem: Brasil. E-mail: profpachecus@hotmail.com 


\section{Introdução}

Ler Paul Ricœur (1913-2005) certamente não é uma tarefa trivial como se possa pensar. A dispersão de seus escritos é uma dificuldade menor se a comparamos com o caráter polifacético de sua produção. A amplitude, a variedade e a abertura de seus interesses é um convite ao debate com a história das ideias. Seus diálogos com autores e pensadores de diversas escolas de pensamento é uma tentativa, realizada no século XX, de atualizar a ágora grega - de abrir uma frutífera discussão sobre os conceitos, as ideias e os problemas que norteiam a sociedade contemporânea.

A reflexão filosófica de Paul Ricœur nasceu, amadureceu no confronto e diálogo constante com as várias expressões do pensamento da história ocidental. "Os pensadores da antiguidade e os contemporâneos encontrarão um observador atento, um interlocutor, um crítico competente e respeitoso” (PACHECO, 2017, p. 59-60).

A linguagem religiosa, para Ricœur, oferece a garantia de acolhimento da revelação como palavra (mot) inacessível e faz com que o homem decida por essa como um dom gratuito. Ela redescreve a realidade, mas a escutando por meio de uma linguagem metafórica e dos símbolos. Esse redescrever nos ajuda a evitar a ilusão de uma linguagem ou de um significado absoluto.

O percurso que o pensador contemporâneo Paul Ricœur iniciou pelos símbolos do mal em Philosophie de la volonté I. Le volontaire et L'involontaire (RICCEUR, 1950), e em seus posteriores estudos, dá-nos um ponto de partida para uma reflexão sobre uma linguagem religiosa nos textos bíblicos.

Nessa reflexão sobre a linguagem religiosa, o pensador francês afirma:

O símbolo dá que pensar; esta sentença que me encanta diz duas coisas: o símbolo dá; eu não ponho o sentido, é ele que dá o sentido, mas aquilo que ele dá, é "que pensar", de que pensar. A partir da doação, a posição. A sentença sugere, portanto, ao mesmo tempo, que tudo está dito em enigma e, contudo, que é sempre preciso tudo começar e recomeçar na dimensão do pensar. É esta articulação do pensamento dado a ele próprio 
no reino dos símbolos e do pensamento ponente e pensante, que eu queria surpreender e compreender. (RICOEUR, 1999, p. 283).

O símbolo tem um sentido que pode ser reapropriado por quem o interpreta. Além disso, na linguagem religiosa há elementos de realidade última que somente podem ser expressos pelos símbolos. Assim, a linguagem simbólica está além do que é apreendido pela razão ou por qualquer outra forma de interpretação. Pode-se mesmo dizer que o símbolo é a linguagem mais íntima do ser, conforme afirma Heidegger: "Trazer a linguagem, sempre novamente, este advento do ser que permanece e em seu permanecer espera pelo homem" (RICOEUR, 1973, p. 372). A linguagem tem um caráter de construtora da realidade e está intimamente ligada à existência humana. E se ela se liga à existência humana, logo pode expressar, através dos textos sagrados, uma esperança.

Esse expressar a esperança se dá através dos textos e dos eventos da manifestação e proclamação, pois é "neste sentido que os símbolos estão ligados no interior do universo sagrado: os símbolos só veem à linguagem na medida em que os próprios elementos do mundo se tornam transparentes" (RICOEUR, 1973, p. 73). Transparentes à medida que há um problema hermenêutico da linguagem dento da tradição cristã, porque ele procede de uma manifestação e de uma proclamação na qual existe uma esperança no evento (que é tudo o que produz, de certa forma, uma mudança dentro da narrativa) da ressurreição e da consumação dos tempos com o advento do evento do Reino de Deus que se aproxima do ser humano.

É dentro desta perspectiva que o objetivo deste artigo é traçar como, em Paul Ricœur, a narração e a sua especificidade da linguagem religiosa permeiam um acontecimento in illo tempore que dá ao homem uma orientação temporal que carrega um acontecimento passado para um futuro que, em certo sentido, é preenchido pela esperança, coroando esforço de ser, de existir do ser humano. 


\section{A hermenêutica dos textos sagrados}

O desejo humano de ser se faz através de um núcleo kerygmático da ética. O evento do kerygma - anúncio - nada mais é que o testemunho que restitui ao ser humano à história do que se perdeu, ou seja, através da morte do justo, tudo está salvo (RICEUR, 1999, p. 336).

É certo que o evento da palavra que se faz carne, um evento histórico como é a encarnação, faz com que a espera nos acontecimentos escatológicos de uma nova palavra, torne-se o "pensamento implícito de toda a fenomenologia dos símbolos, que a princípio acentua a estrutura, depois sublinha a plenitude do símbolo para, enfim, saudar o poder revelador da palavra originária" (PEREIRA, 2004, p. 3).

A hermenêutica dos textos sagrados nos permite fazer um encontro entre a filosofia e a teologia, contudo preservando suas distinções. Implica, ademais, uma redefinição das relações de ambas, da qual Ricœur é testemunho disso em seu itinerário filosófico (VANSINA, 1972, p. 603). Ele mesmo reconhece que, do ponto de visto teórico, caminhou sobre duas pernas e, por ser filósofo, não estava impedido de se dedicar às questões fronteiriças entre a filosofia e a teologia (RICOEUR, 1995, p. 190). Para ele, a relação entre a filosofia e a teologia é mais complexa, diante da linguagem do que a tradição ocidental imaginou, pois a filosofia oferece, muitas vezes, respostas. Porém, por vezes, é a fé teológica que a interroga (RICOEUR, 1999, p. 222). A filosofia, desta maneira, não é somente crítica, mas da ordem da convicção. Por sua vez, a convicção religiosa tem uma dimensão de crítica interna ao pensamento.

Não podemos, mesmo diante das aproximações entre a filosofia e a teologia, esquecer a diferença entre um discurso que vive do dado da fé e que, por isto, proporciona uma palavra que regenera o mais profundo do ser; e um discurso que deixa em suspenso a nomeação de Deus. "O modo diverso que assume a filosofia e a teologia, na linguagem figurativa e na linguagem conceitual, tem equivalente prático nas relações entre a lógica de equivalência e a lógica do dom, entre o ético e o poético, entre a fenomenologia e a manifestação/proclamação, entre a 
hermenêutica filosófica e a hermenêutica teológica" (PACHECO, 2017, p. 230). O certo é que as duas são ouvintes: a teologia é ouvinte da pregação cristã, enquanto a filosofia é ouvinte de uma palavra anterior à própria reflexão, de que esta depende, pois "admitir-se ouvinte, é, logo de início, romper com o projeto caro a determinados filósofos - talvez a todo filósofo - de começar o discurso sem pressuposições" (RICOEUR, 1996, p. 281), logo todo discurso é um acontecimento e a leitura (de um texto, de uma obra) é um novo acontecimento de discurso que é a própria intepretação (RICOEUR, 1971, p. 6-7).

Dito isso, uma reflexão filosófica que pretenda iniciar sua reflexão do zero, que pretenda iniciar a partir de si, sem pressupostos, não é menos dependente que uma teologia que se encerra em uma palavra anterior que não lhe pertence. Contudo, uma filosofia que pretenda começar a partir das verdades que reflexiona, a partir de pontos de intersecções é uma filosofia hermenêutica que não é tomada sem pressupostos, mas que parte para assumir todos os pressupostos. Assim, Ricœur mira a linguagem religiosa (GAGNEBIN, 2006, p. 177) para ser articulada no ambiente de confronto de interpretações.

Para Ricœur, apropriar-se de um texto é apropriar-se de uma variedade de mundos que a linguagem sugere e induz por meio de seu potencial de sentido. "A inserção da linguagem religiosa na perspectiva poética possibilita descrever a realidade de um modo novo, ver os pontos de interseções entre as hermenêuticas filosófica e bíblica" (PACHECO, 2017, p. 180). Possibilita, até mesmo, a mediação da linguagem e da escritura na construção de uma identidade religiosa que fundamenta a sua construção na interpretação de textos, como é o caso particular da linguagem religiosa.

\section{A coisa do texto}

Ricœur é fiel ao seu método. Para ele, o que deve ser interpretado na obra é o mundo do texto e não a intenção escondida do autor que vai buscar no mundo da obra o dado do texto, a coisa do texto. 
Sobre a coisa do texto, Ricœur nos diz que:

[...] a tese hermenêutica, diametralmente oposta à tese estruturalista não ao método e às pesquisas estruturalistas - é que a diferença entre a fala e a escrita não poderia abolir a função fundamental do discurso (o qual engloba estas duas variantes: oral e escrita) O discurso consiste em que alguém diz algo real para alguém sobre algo. Sobre algo: a inalienável função referencial do discurso. A escrita não a abole, mas a transforma. No discurso oral, interlocutores, face a face, podem a título último referenciar aquilo sobre o que falam juntos ao mundo limítrofe que lhes é comum. Apenas a escrita pode, ao dirigir-se a qualquer um que saiba ler, referir-se a um mundo que não está aí entre os interlocutores, a um mundo que é o mundo do texto e que, todavia, não está no texto. Eu o chamo, com Gadamer, a coisa do texto. A coisa do texto, eis objeto da hermenêutica. Ela não está nem atrás do texto como o autor presumido, nem dentro do texto como a sua estrutura, mas desdobrada diante dele. (RICOEUR, 1996, p. 185-186).

A percepção do objeto que se nos apresenta somente pode ser dada diante de uma consciência capaz de percebê-la. A presença é percebida pela consciência sob vários pontos de vista. Entretanto, é na linguagem que se percebe algo (coisa) que não está ali, mas que se deixa transparecer em suas entrelinhas - a palavra transcende toda uma gama de expressões (PACHECO, 2017, p. 30).

Através da escrita o texto é autônomo da intenção do autor e do leitor. O texto assume a configuração de uma obra com um estilo particular que depende de seu gênero literário. $O$ mundo do texto depende daquele estilo e do gênero literário do texto, assim não se pode ressaltar o conteúdo do texto ignorando a forma literária. Como cada método hermenêutico porta um aspecto da realidade, dessa forma cada forma literária porta uma diversa coisa do texto.

Dentro desta discussão, o que os textos bíblicos oferecem para a hermenêutica filosófica é "a interpretação de um texto que se completa na interpretação de si de um sujeito que doravante se compreende melhor, se compreende de outro modo ou que começa mesmo a compreender-se" (RICOEUR, 1994, p. 155). Neste sentido, há uma apropriação da parte do leitor que vence a distância cultural, tornando próprio um sentido que antes era estranho: 
Aquilo de que eu, finalmente, me aproprio é de uma proposta do mundo; [...]. A partir daí, compreender é compreender-se diante do texto. Não impor ao texto a sua própria capacidade finita de compreender, mas expor-se ao texto e receber dele um si mais vasto que seria a proposta da existência, respondendo da maneira mais apropriada à proposta do mundo. (RICOEUR, 1996, p. 186).

Aqui, Ricœur propõe que o que seja interpretado em um texto seja uma proposição de um mundo, de um mundo que possamos habitar. De maneira que, esse texto ou obra literária, abra possibilidades de ser-no-mundo (HEIDEGGER, 1973). Assim a realidade é reescrita na medida em que atua sobre o real.

O que deve ser interpretado num texto é uma proposição de um mundo, de um mundo tal que possamos habitá-lo para nele projetar um dos nossos possíveis mais próprios. A obra literária abre novas possibilidades de ser-no-mundo, do rompimento formal com o ser-dado para o poder - ser. A realidade quotidiana é metamorfoseada na medida em que essa obra literária opera sobre o real

Os textos se referem a um mundo que é o mundo (cultural, temporal, histórico) do texto e esse, o objeto da hermenêutica. O mundo do texto "não está nem atrás do texto como o autor presumido nem dentro do texto como a sua estrutura, mas desdobrada diante dele” (RICOEUR, 1996, p. 1996).

Para Ricœur, o texto transcreve os signos da palavra. Ele é na verdade uma inscrição que tem a intenção de dizer, pois se coloca no lugar da palavra. Assim, a escritura conserva o discurso e o transforma em uma forma disponível as demais gerações de forma permanente e sem alterações para a memória individual e coletiva. O tornar em grafos dos símbolos permite uma tradução analítica e diferenciada de todas as discrepâncias da linguagem. A partir do grafismo, da escritura, o mundo se abre a partir deste. O texto tem a mediação, ou seja, mediatiza o diálogo em seu mundo. A este mundo podemos chamar imaginário, pois está presente pelos escritos no lugar da palavra.

O mundo do texto pode ocultar o mundo em que cada um dos personagens vive, como também pode o enriquecer com sua dimensão significativa. Isso é o que 
permite dizer que: a compreensão de um texto elucida a nossa situação existencial. Ou se podemos dizer, amplifica e ratifica as referências que o texto abre ao mundo.

O mundo, então, corresponde à proposta da existência, pois mundo é o conjunto das referências abertas por todos os tipos de textos descritivos ou poéticos que podem ser lidos e interpretados. É, com efeito, às obras de ficção que devemos, em grande parte, a ampliação do nosso horizonte de existência (RICOEUR, 2012, p. 96-140).

Dessa forma, tem-se que o texto assume uma configuração de obra com um estilo particular dependente do gênero literário. Essa obra abre o mundo do texto a uma referência própria e, consequentemente, a natureza dessa referência é poética, implicando assim, a suspensão da referência ordinária e descritiva, em vista de uma referência dupla e redescritiva da realidade e que revela a pertença do homem ao real por meio da ficção (RICOEUR, 2011, p. 176-178).

Em Ricœur,

[...] o mundo do texto não é, portanto, o da linguagem quotidiana; neste sentido, ele constitui uma nova espécie de distanciação que poderia dizerse do real consigo mesmo. É a distanciação que a ficção introduz na nossa apreensão da realidade. Já dissemos que uma narração, um conto, um poema não existe sem referente. Mas este referente está em ruptura com o da linguagem quotidiana; pela ficção, pela poesia, abrem-se novas possibilidades de ser-no-mundo, na realidade quotidiana; ficção e poesia visam o ser, já não sob a modalidade do ser-dado, mas sob a modalidade do poder-ser. Por isso mesmo, a realidade é metamorfoseada graças ao que poderíamos chamar as variações imaginativas que a literatura opera no real. (RICOEUR, 1994, p. 114).

O mundo do texto, assim, depende tanto do estilo como do gênero literário em que ele foi formado, de modo que não se pode ressaltar o conteúdo do texto desconhecendo a sua forma literária. De forma específica, dentro da linguagem religiosa não se está diante de um discurso descritivo ou cronológico, mas diante de um discurso poético no qual a obra é uma poética generativa e a confissão de fé articulada pela forma de um discurso que se exprime, pois "nomear Deus é, na melhor das hipóteses, uma atividade poética sem incidência sobre a descrição, isto é, sobre o conhecimento verdadeiro do mundo” (RICOEUR, 1996, p. 186-187). 


\section{A linguagem religiosa e a nomeação de Deus}

A linguagem religiosa enquanto é dita através da metáfora - é poética, pois fala sobre o desvelamento do ser no mundo. A poética mostra aquela modalidade do relacionamento do ser humano com o mundo. Uma relação que não se exaure na descrição do objeto, pois para Ricœur "essa função referencial do discurso poético contém, [...], uma primeira aproximação do que pode significar a Revelação no sentido bíblico" (RICOEUR, 1996, p. 188).

A poesia revela, assim, uma verdade que não é aquela de adequação, sobreposta à verificação e à falsificação, mas uma verdade de manifestação da possibilidade do ser humano. Nomear Deus então, para Ricœur, não é tanto fazer teologia ou um ato que o ser humano seja capaz de fazer, é na verdade a revelação de um mundo que podemos habitar, um mundo mostrado pelo texto. Para ele, a nomeação de Deus:

[...] não é simples, mas múltipla. Ou antes, ela não é monocórdia, mas polifônica. As expressões originárias da fé são formas complexas de discurso são tão diversas quanto narrações, profecias, legislações, provérbios, preces, hinos, formulas litúrgicas, escritos sapienciais. Essas formas de discurso nomeiam Deus todas juntas. Mas elas o nomeiam diversamente. (RICOEUR, 1996, p. 189).

Existe na nomeação de Deus um caráter polifônico devido as mais diversas narratividades dos textos sagrados. Nesses textos, a nomeação de Deus é um momento de confissão narrativa é algo que tem seu componente na minha experiência existencial religiosa. Nisso, os diversos discursos e nomeações sobre Deus reatualizam os próprios textos sagrados.

Se é dessa maneira, cabe-nos perguntar que coisa torna os textos poéticos bíblicos em textos religiosos?

A Palavra de Deus, para Ricœur, é farta de problemas filo-teológicos e a nomeação de Deus é um deles, porém aqueles problemas refutam o discurso ontoteológico que tendem a identificar o Ser, a existência e Deus, de tal forma que desemboca na ilusão de tornar Deus o objeto supremo ou o sujeito supremo, pois 
“escutar a pregação cristã para o filósofo é, primeiramente, e desfazer-se de todo saber onto-teológico, mesmo quando a palavra Deus nele figura. O amálgama entre Ser e Deus é sob o ponto de vista uma sedução sútil” (RICOEUR, 1996, p. 189).

A tendência de identificar o Ser com Deus é cessada pela ilusão de tomar Deus como objeto supremo ou sujeito supremo. Essa dupla renúncia ao objeto e ao sujeito absoluto é o preço que se paga para entrar na linguagem radicalmente não especulativa e pré-filosófica da poesia. Por exemplo, pode-se notar que na Bíblia o nome de Deus é polifônico e dependente do tipo de discurso em que é inserido. Esse fato é devido a que a apropriação entre a forma e a confissão de fé é diversificada pela nominação de Deus.

A primeira aplicação hermenêutica geral à exegese bíblica é a de "não construir rapidamente uma teologia da palavra que não inclua, inicialmente e desde o princípio, o passo da palavra a escritura” (RICOEUR, 1994, p. 124). A teologia tem boas razões para privilegiar a palavra em vista da escritura. É a palavra que precede a toda escritura. Jesus foi um pregador e não um escritor, ele mesmo se diz palavra feita carne e, por conseguinte, a Igreja anuncia no Evangelho como palavra de Deus. Assim, encontramos aí as prerrogativas de uma teologia da palavra que unifica a origem, o objeto e as expressões da fé em um único acontecimento - a palavra.

Podemos notar que a relação palavra-escritura se encontra na origem da hermenêutica da pregação cristã, visto que a palavra se relaciona com uma escritura anterior que a interpreta. Jesus interpreta a Tora e Paulo o acontecimento crítico à luz do Antigo Testamento. Esses elementos fazem com que Ricœur conclua que a relação palavra escritura é a constituição do que chamamos: proclamação, kerygma e predicação.

Essa tríade é a condição que possibilita uma tradição, pois a escritura contribui com a distanciação que desliga a mensagem de seu locutor de sua situação inicial e de seu destinatário. Assim, a palavra pode chegar até nós, já não pela voz do proclamador, mas pelo seu sentido e a coisa de que se trata. 
A reflexão filosófico-hermenêutica, ao tirar as consequências da dialética entre palavra e escritura, contribui para o debate aparentemente interno à reflexão teológica. Essa reflexão nos oferece elementos para pensar criticamente uma teologia política até uma teologia da esperança e, ambas, uma teologia da palavra. Há então, um estreitamento entre a palavra e sua narração que não adverte sem que haja os acontecimentos da palavra que são expressos nos textos.

A aplicação de uma hermenêutica centrada nos textos está em uso nas categorias estruturais da exegese bíblica, ou seja, a confissão de fé é inseparável das formas do discurso das estruturas que a sustem.

Ao analisar o discurso narrativo, o profético e o sapiencial, nota-se que cada um desses sublinha uma característica de Deus que pode ser colocada em relação àquela outra forma de discurso.

A narração dos relatos bíblicos é relevante, pois é “aí que Deus é nomeado" (RICOEUR, 1996, p. 190). Deus, portanto, é designado como terceira pessoa, como agente último dos eventos particulares. Deus é, então, uma nominação narrativa. É o Deus de Abraão, do Êxodo, o Deus solidário aos acontecimentos fundadores da comunidade. Esses acontecimentos nomeiam Deus. Nomeá-lo é o primeiro momento da confissão narrativa. É a coisa contada que Deus é nomeado. No discurso narrativo pode-se dizer que prevaleça uma teologia da história, mais que em uma teologia da palavra, pois Deus se mostra na história.

No discurso profético, ao invés de ser nomeado em terceira pessoa, Deus é nomeado em primeira pessoa, articulado pela palavra, pelo diálogo entre um Deus (Ele) e Tu (o ser humano). Na voz do profeta, Deus é significado como voz de Outro detrás da voz profética. Essa voz é consciente de ter sido convocada e enviada. Ela anuncia também os acontecimentos que tem a ver com o dia de Iahweh. Não se trata aqui de acontecimentos fundadores que conta a narração, mas a eminente ameaça que do dia do terror. A forma profética está presente nos oráculos e visões simbólicas que estabelecem uma tensão na ideia de designo de Deus entre uma premonição do futuro e a ideia mais rica da promessa divina. 
Nessa forma, é a palavra que articula e que faz reler os fatos e que se abre a uma inteligência mais profunda. Ricœur nos diz que essa palavra não pode se articular em nenhum sistema, porque entre a segurança que é conferida pela narração dos eventos fundadores e a ameaça anunciada pelo profeta, não há nenhuma síntese racional, mas uma confissão dupla e plena que somente a esperança pode unir (RICOEUR, 2011, p. 155).

O discurso prescritivo assinala um aspecto tanto educativo como ético, pois, nesse discurso, o próprio Deus é autor da lei. Trata-se de um discurso que expressa a vontade de Deus e, por conseguinte, as práticas poéticas e litúrgicas que devem ser praticadas. O caráter concreto da instrução imperativa, dada na Torá - o livro sagrado dos judeus - confirma-se no mandamento e no envio profético. Pois, "o 'tu' da interpelação se torna o 'eu' da responsabilidade” (RICOEUR, 1996, p. 287). O discurso prescritivo não nega as precedentes qualificações de modo que a lei é dada para que se mantenha a aliança entre Deus e o ser humano, conservando assim o evento fundador e libertador sob o anúncio do profeta. Desta forma, evita-se a heteronomia em prol de uma ética da perfeição que parte de Deus e para ele retorna, todavia, passando pela instituição sem se reduzir.

O discurso sapiencial é dirigido a cada homem para além do povo da aliança e, neste caso, é Israel. É uma situação limite em que o ser humano experimenta a sua grandeza e a sua miséria. A sabedoria busca os paralelismos colocados por Deus entre o cosmos e o ethos, entre a ordem do mundo e o agir para encontrar uma harmonia e superar o sofrimento. Esse discurso unido aos outros encontra uma lógica presente no Livro de Jó (que nos ensina que devemos esperar mesmo a despeito do sofrimento), do justo sofredor. Essa lógica não encontra uma explicação na sabedoria para o sofrimento, mas somente em uma ação de fidelidade a Deus. O Deus da Sabedoria é um Deus pessoal que dá a sabedoria e que permanece imperscrutável.

Os hinos, ou melhor, os discursos em forma de hino, no qual os salmos se enquadram, mostram um Deus em segunda pessoa que é invocado na necessidade 
e glorificado na bonança (RICOEUR, 2011, p. 163-165). Nos hinos existe um sentimento que exprime algo em relação a Deus, já que "o referente Deus exprime a circulação de sentido entre todas as formas de discursos em que Deus é nomeado” (RICEUR, 1996, p. 195). O referente Deus é fundado na polifonia bíblica. Contudo, não é enclausurado nessa, mas a transcende. Ricœur nos diz que: “a dialética da nomeação de Deus é que Deus é designado ao mesmo tempo como Aquele que se comunica sob as mais diversas modalidades múltiplas [...] e Aquele que se reserva” (RICEEUR, 1996, p. 195), ou seja, onde ele se manifesta, mas e ao mesmo tempo, guarda para si seu maior segredo: a nomeação inominável.

No discurso religioso há também a presença de um processo qualificatório, que são, do ponto de vista linguístico, os enunciados, as expressões-limite que fazem as diversas pontes socioculturais entre a dimensão religiosa e as demais dimensões presentes na sociedade. Nesse sentido, a "narrativa-parábola repousa na conjunção de uma forma narrativa de um processo metafórico e de um 'qualificador' apropriado que assegure sua convergência com outras formas do discurso que apontam todas para a expressão Reino de Deus" (RICEER, 2006, p. 137).

Cada discurso nos diz algo distinto de Deus ao mostrá-lo como aquele que atua na história; ou, como se apresenta ao longo da história, a passagem da imagem de Deus como o Deus da cólera ao Deus da compaixão ou ainda como o Deus que ordena o cosmo para o Deus que prescreve como deverá ser o ideal de vida ética e social, ora ainda como aquele transcendente a ordem do criado. A forma do discurso, longe de ser indiferente ou um aspecto acessório, determina os traços do Deus que se confessa.

A linguagem religiosa é uma metáfora-limite, ou melhor, toda e qualquer abordagem dialética dessa linguagem se abre ao poder de redescrição. Por exemplo, cada parábola é uma mimésis da realidade em virtude do mythos e da poiésis que a opera. Assim, essa imitação da realidade é, no fundo, um redescrever que está ligado, por diversas formas, ao gênero literário de que ela faz parte. 
A parábola para Ricœur encerra em si um processo metafórico como na narração que consiste não em uma quebra semântica em nível da frase, mas em nível da taxis, da composição de uma obra. Essa quebra indica um referente diverso daquele aparente que ultrapassa a estrutura narrativa. Cada parábola é um elemento de extravagância que não se permite ler como uma narração comum, mas ultrapassa o sentido da narração em direção a um referente ulterior. Ricœur, assim, pensa que o aspecto que ultrapassa a estrutura narrativa seja a especificidade da parábola como um tipo de discurso religioso (RICOEUR, 1996, p. 267-278).

Há, entretanto, uma tensão semântica que está entre a forma narrativa e o processo que impele a ir além dos limites da narração, criando uma incoerência narrativa. Esse processo é o processo metafórico deflagrado pela presença das expressões-limite. Ricœur quer entender como esse processo se dá e investiga todo o corpus das parábolas e faz notar que este forma um sistema próprio em torno da tensão entre uma situação de crise e a resposta a essa situação.

A análise do que é dito, feita no conjunto do Evangelho - contido na Bíblia é a confirmação de que o extraordinário irrompe no ordinário e nos impulsiona a pensar o impensável. Sobre esta questão, Ricœur ressalta:

[...] as primeiras coisas que podem nos impressionar é que as parábolas são narrativas radicalmente profanas. Não há deuses, nem demônios, nem anjos, nem milagres, nem tempo antes do tempo, como na narrativa da criação [...], mas, precisamente gente como nós [...], por um lado, as histórias são narrativas da normalidade, mas por outro, é o Reino de Deus que se diz ser assim: o extraordinário e como o ordinário. (RICOEUR, 2006, p. 206).

Ricœur afirma que a "tensão entre a forma parábola e a forma evangelho é inevitavelmente uma parte da significação da parábola, como narrativa e como metáfora" (RICEUR, 2012, p. 192). Nisso vemos que há uma especificidade da linguagem religiosa que merece ser estudada diante da filosofia, ou melhor, por uma hermenêutica filosófica como aquela que diz de maneira única as narrações e fatos. 
Através da análise linguística a linguagem religiosa pode ser analisada. Ela examina as expressões recorrentes na palavra de Deus, similar ou ainda, da hermenêutica filosófica que se volta a modalidade mais originária da linguagem de uma comunidade de fé. Consequentemente, as expressões com as quais os membros da comunidade interpretam, a título originário, a sua experiência para eles mesmos e para os outros (RICOEUR, 2010, p. 34).

\section{A poética da linguagem religiosa}

Para Ricœur, o filósofo cristão é um “ouvinte da pregação cristã” (RICOEUR, 1968, p. 10). Essa é uma definição que manifesta não só uma sintonia com seu propósito de pensar com todos os pressupostos (RICOEUR, 1996), mas marca a orientação do modo de pensar desse. Ricœur nega que o filosofo deva por entre parênteses o que entende e o que crer como se pudera pensar em tal estado de abstração sobre o essencial. Nega também que deva subordinar a filosofia à teologia em uma relação de servidão, pois entre "a abstenção e a capitulação existe uma via autónoma que situei sob o título de Abordagem Filosófica (RICOEUR, 1999, p. 392)”. Essa é uma via que demanda um esforço enorme e constante de colocar o discurso filosófico em proximidade com o discurso filosófico. Esforço esse que somente é possível através da escuta e na autonomia do pensamento responsável. É um incessante pensar nos limites da simples razão. Como diz o filosofo francês: "viver filosoficamente a esperança cristã como razão reguladora da reflexão, pois a convicção da unidade final do verdadeiro é o próprio Espírito da Razão” (RICOEUR, 1968, p. 11).

Em Ricœur, a linguagem religiosa busca ser pensada, pois ela mesma dá a pensar. Tal afirmação deve enfrentar a objeção que o vínculo externo entre o modo figurativo e o modo conceitual foi extrínseco e imposto de fora. Tal é o caso que, tanto nas origens da cultura cristã, surge dos vínculos entre a religião cristã e o pensamento grego como na situação atual em que parecer haver uma ruptura entre religião e modernidade. 
A cultura judeu-cristã é um dado histórico e, portanto, contingente. Ela nasce nos confins do mundo grego. A influência do helenismo aparece nos dois testamentos e a Igreja cristã foi incapaz de elaborar um discurso teológico sem a conceptualidade grega. O cristianismo tirou do helenismo suas formas de argumentação e até sua semântica fundamental (RICOEUR, 2006, p. 209). A filosofia - linguagem conceitual por excelência - condicionou no Ocidente a linguagem religiosa e a compeliu a tomar a rota do conceito, uma ontoteológia. Dessa maneira, a palavra Deus na Bíblia recebe sua significação da convergência dos diversos modos do discurso teológico, poético-mitológico e filosófico. Sobre essa questão, ressalta-se:

Teve que ser absorvida no espaço temporal para ser reinterpretada em termos do Absoluto filosófico, como o primeiro motor, a causa primeira, o actus essendi, o ser perfeito etc. Daí vem que nosso conceito de Deus pertence a uma ontoteologia na qual continua a organizar a constelação inteira das palavras chaves da semântica teológica, mas no interior de um quadro de significações prescritas pela metafísica. (RICOEUR, 2006, p. 209).

A situação atual da linguagem religiosa não é menos evidente quando a "ontoteológia desmorona sob os golpes da crítica kantiana, da metacrítica marxista, do nihilismo no sentido nistzchiniano, da psicanálise e das ciências humanas" (RICEUR, 2006, p. 209-210). A situação fundamental não mudou radicalmente se a teologia é aprisionada com uma conceptualização anti-onto-teologia. Essa situação segue em função de uma problemática externa que a teologia da secularização e da morte de Deus "apresentam a mesma estrutura formal que a da onto-teologia no passado, são também determinadas cultural e filosoficamente" (RICOEUR, 2006, p. 210).

Entretanto, poderia ser de outro modo? O modelo de Tillich introduz uma relação exterior com a filosofia no âmbito da teologia a qual tem como tarefa uma coordenação da experiência bíblica com a experiência humana (TILLICH, 2005). Ricœur assume o método de correlação "se ele designar que a tarefa formal de ligar entre elas as duas fontes do discurso teológico" (RICOEUR, 2006, p. 210). Entretanto, não se caracteriza o conteúdo de uma teologia regulada por essa 
polaridade de fontes, ou seja, a confrontação dramática desses polos que não poucas vezes na história tem sido "exacerbada pelas paixões demoníacas do clericalismo e do 'livre-pensamento"” (RICOEUR, 2006, p. 210).

A mútua relação entre o significado implantado pela interpretação que a tradição cristã tem de seus textos e o significado estabelecido pela experiência humana ordinária tem um amplo alcance de situações possíveis, "desde a harmonia até a guerra aberta, passando pela coexistência pacífica” (RICOEUR, 2006, p. 211).

De outro lado, perdida a primeira ingenuidade, ligada às estruturas da experiência e tendo a possibilidade de uma segunda ligada as expressões, marca de uma idade pós-critica que qualifica o nosso presente como o tempo das hermenêuticas da suspeita. Um tempo que não requer mediar somente duas fontes, mas duas interpretações: uma autocompreensão da experiência e o discurso cristão e, contra ela, o questionamento radical que uma parte da cultura moderna dirige a qualquer interpretação religiosa da experiência humana. "O conflito das interpretações parece ser a característica existencial inevitável que assume hoje um método de correlação" (RICOEUR, 2006, p. 211). De outro lado, carecemos de conceitos aptos para expressar as tensões e paradoxos próprios dessa situação de confrontação. Isso se deve a termos recebido a conceptualidade outras épocas e de outros momentos supremos de integração cultural e de sonhos articulados em um sistema harmônico.

[...] tempos abençoados das grandes onto-teologias neoplatônicas, das síntese aristotélico-tomista, da teodiceia leibniziana, do sistema hegeliano. De fato, nós pensamos com os destroços e as sobras provenientes dos escombros desses sistemas e - talvez - com os sonhos que esses sistemas trouxeram para a linguagem. (RICOEUR, 2006, p. 211).

Entretanto, quaisquer que sejam os conceitos mais apropriados à presente situação, Ricœur propõe olhar a linguagem religiosa e desdobrar sua capacidade para ser conceitualmente articulada ao ambiente de confrontação da nossa cultura atual. 
Nossa primeira relação com a linguagem não é falar sem escutar. Nessa escuta do acontecimento kerigmático que não tem sua origem em nós, senão na regra de fé, pois a “origem da fé está na solicitação do homem pelo objeto da fé” (RICEEUR, 1965, p. 504). Desde o momento que nos interpela, a questão da fé chega a ser uma questão hermenêutica. Ao chegar a ser palavra audível não pode ser reconhecida, mas que no movimento da intepretação da palavra humana. O que escutamos é uma palavra. O acontecimento kerigmático nos alcança por meio da linguagem e, somente assim, pode dirigir-se a nós interpelar-nos ou solicitar-nos. A acolhida implica em uma ação que não nos é primeiramente ética, mas poética. Uma proposição de mundo, um ser novo que nos é proposto que interpela a nós no mundo que nos pede para imaginar algo distinto do dado. O primeiro a ser interpelado quando nos oferecem as variações a respeito do possível é a nossa imaginação.

Toda uma tradição nos faz olhar para um polo da constituição da linguagem que é proclamada - o Kerygma. O acontecimento-Deus tem constituído a linguagem da esperança que nos chega sedimentada na proclamação e na história da proclamação da comunidade eclesial. Outro polo é o momento de sua apropriação. Diante da tradição vemos um processo de sedimentação das constantes inovações da linguagem da revelação. Olhando o ato de fé e vinculandoo à imaginação criadora que produz o sentido e acolhe o sentido que nos oferece, centramo-nos no momento da inovação que a linguagem da fé produz no sedimentado. A linguagem pela imaginação reveladora.

A revelação é nos dada pelo dado bíblico que chega a nós mediado e interpretado sucessivamente pela tradição. Assim, a fé nos permite a apropriação viva dessa palavra pela condição de que seja, uma vez mais, reinterpretação criativa. Por isso, Ricœur diz que a tradição e a imaginação são aportes para nossas categorias básicas de revelação e fé.

Uma dialética que anima a poética do relato e as relações entre o relato histórico e o relato de ficção é necessária, pois o primeiro na dívida com o passado 
constrito a ser fiel aos testemunhos que o transmitem; o segundo aberto a explorar novos modos de dizer a realidade. Mas ambos tensionados, um pelo outro na medida em que há imaginação na história e realidade histórica no imaginado.

As relações entre fé e poética podem ser fecundas na medida em que fé e confissão são indissociáveis. As análises referentes à dimensão criativa da linguagem terão significativas consequências para a linguagem da fé. Essa estreita relação entre o fenômeno da inovação semântica e da imaginação criadora nos faz vincular fé e imaginação. Porém as relações entre a linguagem da fé e a imaginação criadora requerem um contraponto de uma criação que produz segundo regras, pois se enraíza e é depositaria de uma tradição.

\section{Conclusão}

Ricœur busca descrever e identificar com o auxílio da hermenêutica filosófica as formas do discurso pelo qual a fé da comunidade é expressa. O discurso da polissemia é uma condição da criatividade da linguagem. É graças à polissemia que a linguagem como estrutura e significado findos se abrem a significados infinitos. Deve-se lembrar de que a polissemia nasce do jogo semiológico e do semântico. Ela se desenvolve no interior da frase dentro da obra literária. Mais ainda, na metáfora existe um uso criativo da polissemia, de modo que essa não venha reduzida, mas venha para construir (RICOEUR, 1973, p. 105). Pode-se dizer que esse uso da polissemia requer a suspensão da referência primária para abrir para uma referência secundária. Essa busca é um recuperar das expressões do tipo teológico-especulativas que surgem como conceptualizações da experiência de fé (RICOEUR, 1999, p. 264-281). Essas conceptualizações tornamse depois uma racionalização gnóstica, pois perdem a sua raiz na forma de expressão da fé.

A fé da comunidade vem em forma de linguagem e organiza-se em um discurso no qual estão uma taxis (disposição particular) que articula uma heuresis (descoberta) e uma lexis (expressão, a linguagem como língua). Deste modo, a fé se traduz em um discurso que está em um gênero literário, um estilo, uma mensagem. 
As diversas formas de discurso manifestam significações e expressões diversas da fé que dependem da forma de discurso operada. Esse manifestar é a abertura para um novo mundo - um mundo esquematizado.

O método hermenêutico de Ricœur não parte do objeto, mas de um comportamento estruturado - a experiência de fé na comunidade - que é expressa na linguagem e, assim, delimita um âmbito da realidade sob a qual possibilita a necessidade de indagar a linguagem religiosa. Por um lado, o "sagrado está ligado às suas significações primárias, literais e sensíveis: eis o que faz a sua opacidade; por outro lado, a significação literal encontra-se ligada pelo sentido simbólico que nela reside: [...] o poder relevante do símbolo" (RICOEUR, 1950, p. 39).

Por fim, afirma-se que o texto sagrado (texto bíblico) em Ricœur é uma janela aberta, uma possibilidade tanto do processo ético de nomeação de Deus como também da abertura e da complexidade poética da construção do texto. Neste caso, o texto sagrado como da relação do ser humano com este mesmo texto.

\section{REFERÊNCIAS}

GAGNEBIN, Jeanne Marie. Lembrar, escrever, esquecer. São Paulo: Editora 34, 2006.

HEIDEGGER, Martin. Conferências e escritos filosóficos. Tradução Ernildo Stein. São Paulo: Abril Cultural, 1973. (Coleção Os Pensadores).

PACHECO, Márcio Lima. Paul Ricour: a esperança como movimento da existência no evento da ressurreição. São Paulo, 2017. Tese (Doutorado em Filosofia) - Faculdade de Filosofia, Comunicação, Letras e Artes, Pontifícia Universidade Católica de São Paulo.

PEREIRA, Miguel Baptista. Para uma filosofia do símbolo. Revista de Filosofia de Coimbra, Portugal, n. 25, p. 3-30, 2004.

RICOEUR, Paul. La philosophie et la spécificité du langage religieux. Revue d'histoire et de Philosophie Religieuses, Paris, n. 55, p. 13-26, 1975.

RICOEUR, Paul. A hermenêutica bíblica. Tradução Paulo Meneses. São Paulo: Loyola, 2006. 
RICOEUR, Paul. Creativity in Language: Word, Polysemy, Metaphor. Philosophy Today, Virgínia, v. 17, n. 2, p. 97-111, Summer 1973.

RICOEUR, Paul. De l'interprétation. Essai sur Sigmund Freud. Paris: Le Seuil, 1965.

RICOEUR, Paul. Do texto à ação: ensaios de hermenêutica II. Tradução Alcino Cartaxo e Maria José Sarabando. Porto: Rés Editora, 1994.

RICOEUR, Paul. Escritos e conferências 2: hermenêutica. Tradução Lúcia Pereira de Souza. São Paulo: Loyola, 2011.

RICOEUR, Paul. História e verdade. São Paulo: Forense, 1968.

RICOEUR, Paul. Leituras 1: em torno ao político. Tradução Marcelo Perine. São Paulo: Loyola, 1995.

RICOEUR, Paul. Leituras 3: nas fronteiras da filosofia. Tradução Nicolás Nyimi Campanário. São Paulo: Loyola, 1996.

RICOEUR, Paul. Manifestation et proclamation. In: CASTELLI, E. Il sacro: studi e ricerche. Roma: Istituto di Studi Filosofici, 1971. p. 57-76.

RICOEUR, Paul. O conflito das interpretações: ensaios de hermenêutica I. Porto: Rés Editora, 1999.

RICOEUR, Paul. Philosophie de la volonté I. Le volontaire et l'involontaire. Paris: Aubier; Montaigne, 1950.

RICOEUR, Paul. Tempo e narrativa 1: a intriga e a narrativa histórica. Tradução Claudia Berliner. São Paulo: Martins Fontes, 2012.

RICOEUR, Paul; CHAGEUX, Jean- Pierre. La natura e la regola: alla radici del pensiero. Milano: Raffaelllo Cortina Editore, 2010.

TILLICH, Paul. Teologia sistemática. 5. ed. São Leopoldo: Escola Superior de Teologia; Sinodal, 2005.

VANSINA, Frans D. La problématique épochale chez P. Ricoeur et l'existentialisme. Revue Philosophique de Louvain, Louvain, v. 70, n. 8, p. 587-619, 1972. 